\title{
Relationship between Organizational Work Life Balance Factors and Executive Employee's Performance in Selected IT Organizations in Sri Lanka
}

\author{
W. T. A. Nilashini \\ MBA scholar \\ University of Sri Jayewardenepura \\ Thanthrige87@gmail.com
}

T. L. Sajeevanie

Senior Lecturer

Faculty of Management Studies and Commerce

University of Sri Jayewardenepura

tlsajeevanie@sjp.ac.lk

Cite this article: Nilashini, W.T.A. and Sajeevanie, T.L. (2018), Relationship between Organizational Work Life Balance Factors and Executive Employee's Performance in Selected IT Organizations in Sri Lanka, Sri Lankan Journal of Human Resource Management, Vol. 8, No.1, pp. 1-22. 


\begin{abstract}
Work Life Balance is a challenging concern among many employees. The main purpose of this study was to explore the experiences of IT executives of organizational work life balance factors and to observe the relationship between those identified organizational work life balance factors and employee's performance. The conceptual framework was developed based on the Social Exchange Theory presented by Thibaut and Kelly (1959). To achieve the main purpose, three hypotheses were developed and tested. Hypothesis testing was chosen as the type of study and it was conducted in non-contrived setting. The study was cross-sectional in time, and primary data were collected by using convenient and random sampling. The sample size of this study was 223 executives who are working in leading Information Technology organizations in Sri Lanka. The unit of analysis was at individual level. Preliminary analysis was performed to test normality, validity and reliability. Findings of the analysis disclosed that all considered organizational work life balance factors significantly and positively related to the employee performance. Among all the relationships, work life balance policies had a weak relationship with employee performance. As per the results obtained via the analysis, this study provides valuable insights to managers, policy makers and others regarding the importance of organizational work life balance factors. This study mainly focused on organizational work life balance factors than other factors such as individual and environmental factors. This was the major limitation of the study and it can be suggested for future studies to conduct research covering those factors.
\end{abstract}

Key Words: Employee Performance, Information Technology, Organizational Work Life Balance Factors

\title{
Introduction
}

According to Guest (2002) Work Life Balance (WLB) is always a concern of those interested in the value of work and family lives. Discussions on elements such as WLB policies, supportive work environment and job characteristics have become more popular topics in both the academic work and in practice. Even though, WLB is an intuitively emerged concept, it has no clear definition (Pringle et al., 2003). According to Kumarasamy et al. (2015) there are many factors effecting WLB mainly categorized under three main headings as individual factors, organizational factors and environmental factors. The concept of WLB is comparatively wider than WLB policies. Therefore, people may desire for balance in all aspects of life in a way that resources are dedicated among all lives (Kirchmeyer, 2000). WLB can be outlined to work-life conflicts and challenges faced by a person in trying to attempt finding a balance in both circumstances such as internal and external work environments. WLB is significant to minimize work family conflicts since most of the individuals play multiple roles in their lives (Lero and Bardoel, 2009). Besides, the concept WLB helps to understand the work and non-work aspects and areas of life (Gregory and Milner, 2009). Maertz and Boyar (2009) have explained WLB as a specific combination of organizational policies, organizational practices and programmes and a philosophy which automatically supports employees to achieve work and family responsibilities successfully. WLB programmes consist of employee awareness programmes conducted by human resource 
departments, employee rewards, training and development programs, etc. All of which tackle the substantial relationships of employees, families, societies and the workplace. The aim of WLB is to lead a harmonizing life. The central thrust of WLB is that work and private lives are viewed more as harmonizing ingredients of a complete life than as challenging priorities. Lewis (2008) added that realization has to do with assuming a method thought of as a collaborative course of action entailing a reflection on the desires of both the workers and the employers. Among the different descriptions and explanations of WLB, it is heavily linked with maintaining the symmetry and wisdom of synchronization in life. Attaining WLB has so many positive implications in the life of individuals that eventually affect the organizations enjoying success and competitive advantages. Work-life imbalances are associated with a variety of negative consequences on both family and work, such as depression, high employee turnover, job and life dissatisfaction and stress (Allen, Bradley and Brown, 2000). According to Baltes et al., (1999) WLB is associated with job satisfaction, life satisfaction, employee productivity, absenteeism and turnover. The support provided by the work domain will greatly influence the balance between work and life. The familyfriendly benefits available in the company will increase the commitment, employee motivation, increase employee intention to stay in the organization and reduce labor turnover. However, Henry and Anderson (2009) also suggested that the mere existence of WLB policies is inadequate to ensure employee WLB or to reduce work life conflicts. Employees must build a supportive work environment that promotes the use of such WLB policies (Thompson, Chandra and Charanjeet, 1999).However, the WLB concept has often been criticized, evaluated and reviewed. For this reason, it is important to study WLB factors such as supportive work environment and to examine the relationship between organizational WLB factors and employee performance, especially in countries like Sri Lanka and industries like Information Technology (IT) due to lack of literature available. This paper firstly provides the relevant literature and past research findings and then the conceptualization of the study is presented. The methodology employed is described henceforth and a result with a discussion ensues.

\section{Work}

"Work" was originally described as paid employment by scholars. But Guest (2002) argued that the extra unpaid working hours, the time it takes to travel to work place and work from home, must be also taken into account. For this study, the work was defined as the amount of time and effort that an individual spends working in a particular organization.

\section{Life}

Life can be considered as non-work life, home or family. Guest (2002) has initially described life (similar to family or non-work life) as activities outside work. For this study, family is considered as the duration and effort an individual spends outside the work being a member of a certain family. It is possible to give a broad view of life which consists of several aspects including work life, family life, social life, academic life, religious life, recreational life and others. Though some studies have used the word "family" instead of "life" in this study it is considered as the word for life and the word, family have similar meanings. For the purpose of this study, the term "life" was used. 


\section{Work Life Balance}

The concept WLB is also known as "work-family balance" (Clark, 2000) "Work-Personal Life Balance"(Lewis et al., 2003) "Work-Life Integration" (Pocock, 2005) "Work-Personal Life Integration" (Lewis et al., 2003) "Work-Family Interaction" (Lo, 2003) and "Work-Family fit" (Clark, 2000). According to Lewis et al. (2003) these terms have been evolving for over four decades. Work-family balance is a sub set of WLB (Pronk, 2005). Employees and organizations provided special attention on WLB during recent years. Employees face many complications to attain demands coming from family and work. In work environment technological advancement, information overload is increasing the burden on employees (Guest, 2002) and growing customer expectations (Woodward, 2007) can be considered as another cause of work-family imbalance. These sources create imbalance between work and family responsibilities. Hence, work-family balance is one of the most challenging and important concepts (Clark, 2000; Nisansala and Sajeevanie, 2017) and according to Lewis et al. (2003) it is a hot topic in the twenty-first century. WLB is maintaining a balance between responsibilities at work and at home (Cieri et al., 2005). According to Hughes and Bozionelos (2007) WLB is the ability of individuals, regardless of age or gender to find a rhythm that allows them to combine their work duties and aspirations. Greenblatt (2002) described WLB as the absence of undesirable level of conflicts between work and non-work requirements, indicating that conflicts may arise when work and family demands are conflicting and opposing. According to Hill et al. (2001) WLB is how a person concurrently balances the emotional, temporal and behavioral demands of both work and personal activities. Clark (2000) explained that WLB as good functioning, fulfillment and satisfaction at work and home with a less role conflicts. This definition is considered as the working definition of WLB for this study. Further, Clark (2000) described WLB as how an individual achieves and plays successful role in both work and non-work life with negligible role conflicts.There are many aspects that contribute to the requirement for WLB because it directly benefits the employee, employer and others. According to Pocock (2005) employees who are happy with their WLB are likely to be satisfied parents, public citizens and more efficient and effective workers in the organization. Also, WLB enhances the job satisfaction and job engagement. Simply, WLB contributes to the social wellbeing by being more productive, more public contribution, their health along with the health of the others such as dependents and parents. McDonald and Bradley (2005) explained the benefits of good WLB in both employer and employee aspects. Less absenteeism, high employee performance, high employee retention, less employee turnover, improved health and higher degree of job satisfaction of the employee were some of the benefits elaborated by McDonald and Bradley (2005). Opatha (2019, p. 142) writes: WFB will result in both the employer's happiness and family members' happiness.

\section{Factors Effecting WLB}

Different researchers have classified the factors effecting WLB in different manner. According to Kumarasamy et al. (2015) there are three types of factors effecting WLB namely, Individual factors, Organizational factors and Environmental factors. Based on the above classification emotional intelligence, spiritual intelligence and job engagement were categorized under individual factors. Under organizational factors supportive work 
environment, WLB policies and job characteristics were discussed. Finally, environmental factors such as technological advancement in improving the workforce WLB were explained.

\section{Work Life Balance in IT Sector}

The concern of employees from information technology (IT) industry towards WLB has drawn increasing attention among researchers. As described by Scholarios and Marks (2004), the nature of work which differentiates work and non-work life being considerably more unclear than for more traditional professions make IT professionals face more WLB issues. Offsite client work (Weisenfeld, Raghuram and Garud, 2001) and schedule flexibility, which may mean uncertainty in some cases are typical in IT industry. Consequently, the possibility of overlap between work life and personal life is higher. Also, employees from IT industry usually work long hours (Perlow, 1998). For instance, majority of the software workers believed that in order to achieve progress in their career lives they are expected to sacrifice most of their personal lives commitments and responsibilities.

\section{Work Life Balance in Sri Lanka}

In the Sri Lankan context, WLB has not taken into discussion greatly and the reason can be seen as the culture of Sri Lanka where father was the employee and mother was the homemaker. At present with the open economy, both mother and father engaged in work. Later in Sri Lanka WLB has become a burning issue with globalization and technology advancements, simultaneously WLB has become a warm and significant topic in Sri Lanka. Significance of having WLB can be identified from this statement, taken from Opatha (2007). He has stated that it is commonly agreed that when a person is happy in his or her personal life, in other words family life, he or she is more efficient and he is effective at work life and it can be said that there is vital importance of studying the factors affecting work family balance of one's life, especially in a country like Sri Lanka due to having a lack of literature on this topic.

\section{Social Exchange Theory as a Contemporary Approach to WLB}

Social exchange theory goes back to twentieth century and the key points of the theory were developed out of its presentation to family science by George (2009). This theory was produced through a convergence of psychology, sociology and economics. In addition to that, Sullivan and Lewis (2001) illustrated that the employees will achieve better when they feel they obtain the social advantage which they intend to get. This theory is helpful in differentiating positive results related to apparent organizational support, policies such as leave, alternative work arrangements and job characteristics. As indicated by Muse and Stamper (2007) in social exchange the parties involved will act now in the expectation of future indistinct rewards. This suggests firms that give actual support in all aspects can expect positive responses from their staff. More noteworthy level of support ought to identify decline in work-family conflict and also higher impression of organization support, which can be required to bring about lower mental pressure, higher responsibility, commitment and lower turnover expectations. Social exchange theory indicates the instances where the people feel committed to interchange when they account advantages 
from another one's activities (Lambert, 2000). Gouldner (1960) illustrate that, in the rule of interchangeability the one who is obtaining the benefits becomes forced to atonement of the donor. As per Lambert (2000) advancements in social exchange theory prefer that the work -family advantages can improve involvement and commitment of employees to give better performance for additional benefits. Stevens et al. (2006) through their survey of employer's attitudes and a companion investigation of employees' attitudes figured out that 94\% of employers and $95 \%$ of employees provide their consent for the statement of people work best when they can balance their work and other aspects of their lives.

\section{Employee Performance}

Performance can be taken as outcomes or results created on a specified job or an activity during an identified time period. Organizations cannot be prospered without having valuable employees. Every employee has a purpose to perform. Employee performance is individual's behavior or what employees do in an organisation. Characteristics of employee performance can be evaluated as positive, neutral or negative for employee his/ herself and organizational effectiveness. Employee performance is multidimensional thus there may be various types of behaviors that have the ability to enhance or hinder the goal achievement of an organization (Aguinis, 2009). Major determinants of employee performance involve, employee performance $=$ Declaratives knowledge $*$ Procedural knowledge * Employee Motivation and employee performance can be measured by using traits, behavior and results approaches (Aguinis, 2009). Trait approach considered the individual performer and ignores the specific situation, results and behavior. The traits of the employee consisted of abilities, like cognitive abilities, that cannot be easily trainable and which will not change over time. This approach is acceptable based on the positive relationship between abilities, personality traits and desirable work related behaviors required. The traits of the employees consist of their job knowledge, cooperation, dependability, interpersonal relations, ethics and integrity, new ideas and communication skills. The behavior approach considers what employees perform on the job and does not emphasize traits of the employees or the outcomes resulting from their behaviors. This considers how the employees do the job and this is a process - oriented approach. Behavior approach is more appropriate in a situation where the connection between results and behaviours is not clear, the results occur in a distant future and there are poor outcomes due to causes beyond the control of the performer. The behaviors of the employees consist of their planning to work, organizing work, discipline, attendance and speed (Opatha, 2002). Aguinis (2009) stated that the results approach considers the outcomes of the employees. The results approach is most suitable when the workers are skilled in the needed behaviors, when there is an obvious relationship between behaviors and results, when there is a consistent improvement in the results overtime. The results of the employees consist of quantity of work, quality of work, efficiency achievements and completion of work on time (Opatha, 2002). Armstrong (2000) expressed that it was significant to classify the meaning of employee performance because if performance cannot be clearly defined it cannot be measured or managed. In today's competitive business environment getting the maximum contribution from each and every employee is quite challenging. Further, he stated that, each organization should have a clear 
definition about employee performance in order to implement the performance appraisal system effectively.

\section{Factors Effecting Employee Performance}

According to the latest study conducted by Soomro, Gilal and Jatoi (2011) job description, selection, rewards, training and development and performance appraisals have positive relationships with employee performance. Further, the study uncovers that good performance appraisal system and employee compensation have a greater impact on the improvement of the employee performance. Human resource initiatives such as providing informal and formal training have a positive impact on market value, employee performance and productivity (Delery and Doty, 1996). The reward system based on the performance of the employees, leads to sustain high performance at work, enhance the quantity, quality of their output (productivity) and create a good assurance over the target they have to achieve within the given schedule. They are responsible to guarantee the process quality by doing things right at the first time.

\section{Importance of Employee Performance}

According to Otley (1999) organization performance can be branded to two categories namely, organizational performance and employee performance. Based on the research findings organizational performance is dependent on the individual performance and other factors such as the working environment of the organization. In order to meet the organizational goals and objectives successfully, it is evident that the organization should pay attention to organizational performance. In other words, focus should be given on effective implementation of appropriate strategy (Otley, 1999) to ensure employee performance (Hunter, 1986).

\section{Theoretical Framework}

For this study the theoretical framework given in Exhibit 1 was developed and three independent variables and one dependent variable, i.e. employee performance exist in the network of relationships.

\section{The Relationship between Work Life Balance Policies and Employee Performance}

According to Moore (1998) in order to help the employee to achieve organizational and family responsibilities and demands, organisations do arrange many family-friendly policies such as flexible working arrangement, part time jobs, elderly care and child care facilities, etc. Such provisions are typically named as WLB policies or family friendly policies (Osterman, 1995; Dex and Bond, 2005). Benefits for individuals and organisations of such provisions include reduced work-family conflict (Thomas and Ganster, 1995), increased organizational citizenship behavior (Lambert, 2000), increased organizational commitment (Kopelman et al., 2006) and increased employee performance and job satisfaction (Thompson and Prottas, 2006; Kossek and Ozeki, 1999). Thus, it is hypothesized that: $\mathrm{H}$ 1: There is a positive relationship between WLB policies and employee performance. 
Figure 1: Theoretical Framework

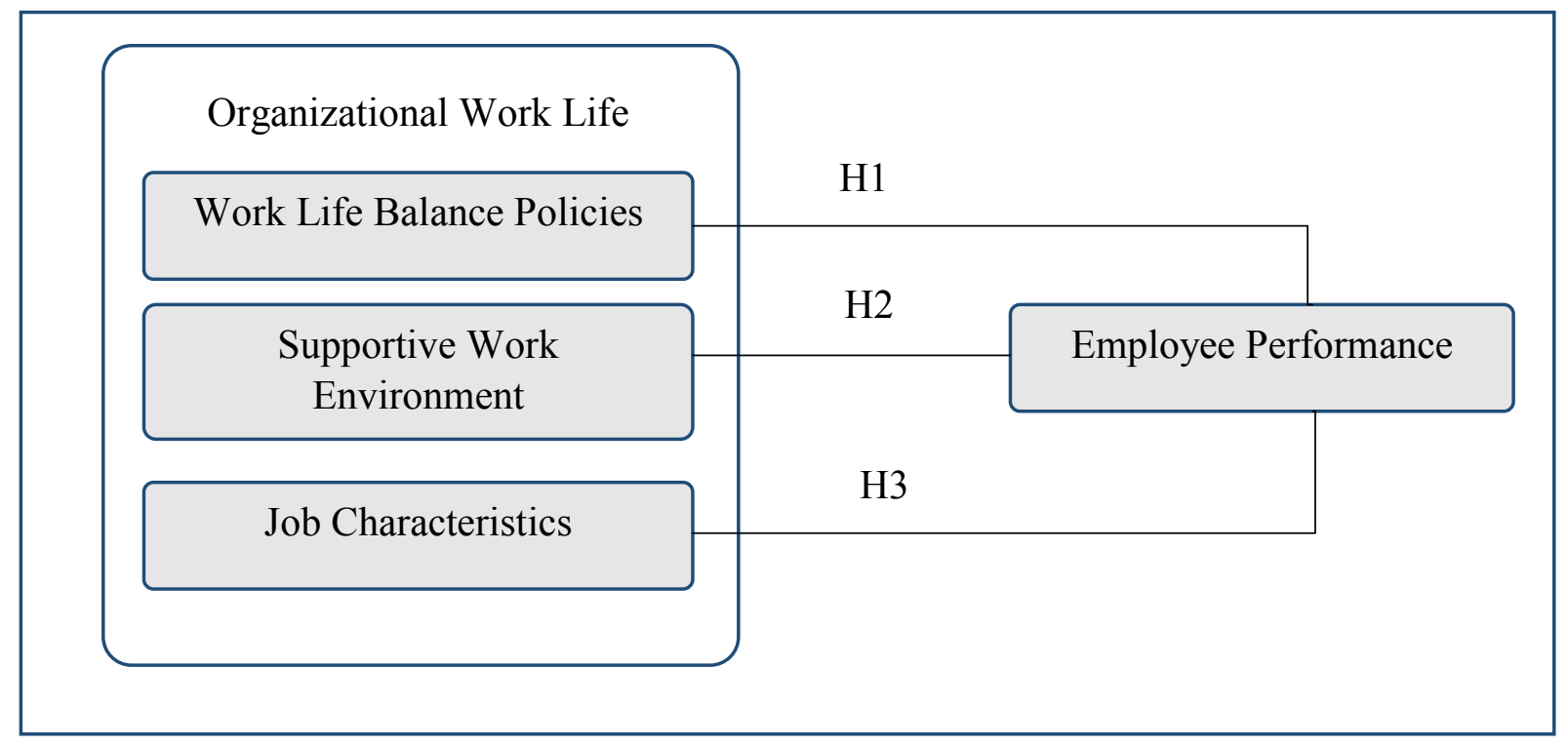

Source: Adapted from Social Exchange Theory by Thibaut and Kelly (1959)

The Relationship between Supportive Work Environment and Employee Performance Supportive work environment enhances the employee flexibility, employee loyalty and selfacceptance (Friedman and Greenhaus, 2000) which apparently enhances positive attitude towards work. According to Wayne et al. (2006) employee well-being in both work and family and employee performance may enhance with employee satisfaction. Therefore, it is hypothesized that:

$\mathrm{H} 2$ : There is a positive relationship between supportive work environment and employee performance.

\section{The Relationship between Job Characteristics and Employee Performance}

According to Kahn (1990) having jobs that consist of core job dimensions such as autonomy, task variety, task identity, task significance and feedback results in personal fulfillment and motivation of employees. As a result, employees feel more satisfied with their occupation (Loher et al., 1985) which will lead to employee performance and show high employee job engagement towards their organization (Flynn and Tannenbum, 1993). Thus, it is hypothesized that:

H3: There is a positive relationship between job characteristics and employee performance.

\section{Methodology}

This study was conducted based on quantitative approach. The population considered for this study was the IT executives in the selected four IT organizations. By using convenient sampling organizations were selected and by using simple random sampling executives were selected as the sample and the sample size was 223. The unit of analysis was at the 
individual level. In order to measure the perceived degree of WLB, online questionnaires were distributed. The questionnaire used for this study consists of two parts. The first part covered demographic factors such as gender, marital status, age, experience and education. The second part covered the main variables such as organizational WLB factors, and employee performance. The study was directed in a non-contrived setting, in other words, in a natural setting with minimum interference of the researcher. Data for this study were collected at a single point in time (Sekaran, 2006; Opatha, 2003) the study was crosssectional in time horizon. The primary data gathered were coded and analyzed by using the SPSS (Statistical Package for Social Sciences) Version 21.

\section{Testing Hypotheses}

\section{Relationship between WLB Policies and Employee Performance}

To test the relationship between WLB Policies and employee performance the first hypothesis was formulated as below.

H1: There is a positive relationship between WLB policies and employee performance.

The null hypothesis was formulated as, Ho: There is no positive relationship between WLB policies and employee performance.

Table 1: Pearson Correlation Coefficient of H1

\begin{tabular}{|l|l|l|}
\hline \multicolumn{2}{|l|}{} & $\begin{array}{l}\text { Employee } \\
\text { Performance }\end{array}$ \\
\hline \multirow{4}{*}{ WLB Policies } & Pearson Correlation & .152 \\
\cline { 2 - 3 } & Sig. (2-tailed) & .023 \\
\cline { 2 - 3 } & N & 223 \\
\hline
\end{tabular}

According to the results of the Pearson's correlation shown in the Table 1, there is a positive relationship between WLB policies and employee performance of the respondents. A positive relationship between WLB policies and employee performance exists as Pearson correlation between the two variables is 0.152 . Though the relationship is positive and according to Pallant (2013) it is not much strong. The Sig value is $0.023(0.023<0.05)$ therefore, the relationship is significant. Thus, there is statistical evidence to claim that WLB policies and employee performance are positively related. Hence the alternative hypothesis is accepted.

\section{Relationship between Supportive Work Environment and Employee Performance}

To test the relationship between supportive work environment and employee performance the Second hypothesis is formulated as below.

$\mathrm{H} 1$ : There is a positive relationship between supportive work environment and employee performance.

The null hypothesis was formulated as, Ho: There is no positive relationship between supportive work environment and employee performance. 
Table 2: Pearson Correlation Coefficient of $\mathrm{H}_{2}$

\begin{tabular}{|l|l|l|}
\hline \multicolumn{2}{|l|}{} & $\begin{array}{l}\text { Employee } \\
\text { Performance }\end{array}$ \\
\hline \multirow{4}{*}{$\begin{array}{l}\text { supportive work } \\
\text { environment }\end{array}$} & Pearson Correlation & .469 \\
\cline { 2 - 3 } & Sig. (2-tailed) & .000 \\
\cline { 2 - 3 } & $\mathrm{N}$ & 223 \\
\hline
\end{tabular}

Based on the results of the Pearson's correlation shown in the Table 2, there is a positive significant relationship between supportive work environment and employee performance of the respondents. Pearson correlation between the two variables is 0.469 , which is positive. It shows that there is a positive relationship between supportive work environment and employee performance and that relationship is statistically significant. According to Pallant(2013), the relationship is strong and significant since the sig value is $0.000(0.000<$ 0.05 ) Thus, there is statistical evidence to claim that supportive work environment and employee performance are positively related. Therefore, the alternative hypothesis is accepted.

\section{Relationship between Job Characteristics and Employee Performance}

To test the relationship between job characteristics and employee performance the third hypothesis is formulated as below.

$\mathrm{H} 1$ : There is a positive relationship between job characteristics and employee performance.

The null hypothesis was formulated as,

Ho: There is no positive relationship between job characteristics and employee performance.

Table 3: Pearson Correlation Coefficient of $\mathrm{H}_{3}$

\begin{tabular}{|l|l|l|}
\hline \multicolumn{2}{|c|}{} & $\begin{array}{l}\text { Employee } \\
\text { Performance }\end{array}$ \\
\hline \multirow{4}{*}{$\begin{array}{l}\text { Job } \\
\text { Characteristics }\end{array}$} & Pearson Correlation & .576 \\
\cline { 2 - 3 } & Sig. (2-tailed) & .000 \\
\cline { 2 - 3 } & $\mathrm{N}$ & 223 \\
\hline
\end{tabular}

According to the results of the Pearson's correlation shown in the Table 3, there is a positive relationship between job characteristics and employee performance of the respondents. Pearson correlation between the two variables is 0.576 which is positive. According to Pallant(2013) correlation coefficient is strong. The found relationship is significant since the sig value is $0.000(0.000<0.05)$. A positive relationship exists between job characteristics and employee performance Thus, there is statistical evidence to claim that job characteristics and employee performance are positively related. Hence, the alternative hypothesis is accepted. 


\section{Discussion and Conclusion}

Based on the 223 respondents, it was found that the most of the respondents in the sample was Male. It was 165 respondents of the sample which is $74 \%$ of the total respectively. Only 58 respondents were female. Korpunen and Napravnlkova (2008) stated that it is hard to hire women employees for important, leading and challenging positions as most of the women employees give more focus on achieving family demands by sacrificing their career life. Therefore, it can be seen that female representation in IT sector is less in Sri Lanka due to high level of work load, stress and many other challenging factors. According to the selected sample 80 were single and 135 were married respondents, which is $39.5 \%$ and $60.5 \%$ of the total respectively. Further to the analysis it was identified that most of the married respondents were male. Researchers (Santos and Cardoso, 2008; Thanacoody et al., 2006) have observed that family responsibilities such as house work and childcare act as a barrier for the performance of the married woman in their career. Thus, it was observed that the employee retention of the married women was less compared to the married men.

Based on the frequency analysis, $45.3 \%$ of the respondents were within the age group of below 30 years, $25 \%$ of the respondents were aged between 31 and 40 years, $18.8 \%$ of the respondents were aged between 41-50 years. Those who are above 51 years were just $9 \%$ of the total. According to Dex and Bond (2005) age is one of the most significant factors in determining WLB and they found that WLB difficulties were greater as age increased. Further, based on the discussions held with the HR managers in the selected organisation, employee turnover is more among older adults and younger adults are more prone in experiencing more conflicts, stress compared to older adults. The questionnaires were distributed randomly among the sample of four groups in years of service ranging from below 4 years to above 15 years. 109 respondents belonged to below 4 year service category, and 6 respondents belonged to more than 15 years of experience category; further, there was a gradual decrease of the number of respondents as experience increased. According to the Carayon et al. (2003) employees shift from one job to another within a short period of time. Therefore, employee retention is less in IT industry. Based on the analysis $3.1 \%$ of the respondents have obtained a diploma qualification. Percentage of respondents with graduate qualification is $75.3 \%, 17 \%$ of the respondents have obtained postgraduate qualification and $2.2 \%$ of the respondents have obtained other qualifications. According to the discussion carried with the HR Managers graduate level or postgraduate level qualification is mandatory for executive level positions. Based on the empirical data level of education of the executives have impact on WLB. A positive relationship between WLB policies and employee performance can be seen as Pearson correlation between the two variables is 0.152 . Though the relationship is positive, it is not much strong. The Sig value is $0.023(0.023<0.05)$, therefore, the relationship is significant. According to the research finding of Brough, O'Discoll and Kalliath (2005) the use of organizational family friendly WLB policies tends to improve employee performance and to improve the organizational outcome. According to the analysis, it was found that supportive work environment and employee performance are positively related. Findings of the previous literature evidences show that there is a strong relationship between supportive work environment and employee performance (Kossek and Ozeki, 1999; Kopelman et al., 2006; Lambert, 2000). 
Also, organisations gain employee loyalty in return by providing supportive work environment. (Kopelman et al., 2006). It was founded that job characteristics and employee performance are positively related. The positive relationship between job characteristics and employee performance opposes the findings of Beutell and Wittig-Berman (2008) and is consistent with that of Voydanoff (2004) and Thompson and Prottas (2006). These researchers have used job autonomy as the only measure of job characteristics, but in this study other measures of job characteristics such as skill variety, task identity, task significance and feedback were considered and they have the potential to enhance the level of employee performance. In conclusion, this research examined the relationship between organizational WLB factors and employee performance of IT executives in Sri Lanka. The results suggest that there is a statistically significant positive relationship between organizational WLB factors (WLB policies, supportive work environment and job characteristics) and employee performance.

\section{Theoretical Implications}

The findings of this study provided an insight into the existing theory of organizational WLB factors and employee performance. Some of the findings were not inconsistent with Western culture. This study showed that culture may be a factor that can influence organizational WLB factors and employee performance which should be further investigated.

\section{Empirical Implications}

The research suggests several possible managerial implications. The findings of this study indicate that organizational WLB factors are significantly and positively related to employee performance. Hence, to increase the level of employee performance of IT executives, it is needed to address the issue related to WLB factors by the management. However, few researchers have done their studies to identify a relationship between organizational WLB factors and employee performance. According to the findings of this study, the organisations can improve employee performance by adopting WLB supportive policies at work. The reason is that friendly policies help to create a family supportive organizational environment. For example, as explained in the literature long working hour culture is common for IT industry but long working hours lead to higher levels of stress, poor job commitment, poor productivity, high absenteeism and turnover (Higgins et al., 1994). Accordingly, these long working hours become harmful for employee well-being as well as for the development of the organization. Hence, it is important to pay attention to flexible working hours and other arrangements in order to improve employee performance. HR practitioners are required to learn about the changing aspects of supportive work environment and must work towards strategically planning and implementing such supportive work environment practices for better retention of employees. The findings of the study explained that when employees are provided with satisfactory supervisory support, good peer relationship they will be more engaged the organization. Supportive work environment causes to improve employee job satisfaction and employee performance. Therefore, employees tend to remain in the same organization for a long run. HR Practitioners need to become familiar with the changing aspects of supportive work 
environment and work to strategically design and implement such supportive work environment practices in the organization for better employee retention. The findings of the study indicated that if staff members receive satisfactory support from the supervisor and good peer relationship they will be more engaged in the organization. Supportive work environment improves employee performance. Therefore, employees tend to stay in the same organization in the long run. This study contributed to the importance of human resource development that would enhance the understanding the importance of job design which creates motivation to work. Therefore, job design would lead to balance between different employees and job requirements (Schermerhorn, 2005). In designing jobs, fundamental job characteristics namely, skill variety, task identity, task significance, autonomy and feedback are to be seriously considered in order to improve employee performance.

\section{Limitations}

The study was limited to examine the relationship between the Organizational WLB Factors and employee performance and it did not consider other factors such as individual and environmental factors. This study was conducted among the IT executives in Sri Lanka, excluding the other types of the employee levels and industries and this is another limitation. Another limitation of this study is that the job performance of the employees was measured based on their own judgment. In this study a structured questionnaire was used for data collection and it limited the opportunity to collect data in depth about their WLB employee performance. Despite these limitations, it is believed that this research makes a significant contribution to the existing literature of WLB.

\section{Further Studies}

This research mainly focused on finding a relationship between organizational WLB factors and employee performance of executives employed in Sri Lankan IT industry. Based on the literature many other factors affect employee WLB such as job engagement, emotional intelligence, spiritual intelligence, technological advancements, etc. which can be categorized under individual factors and environmental factors. Therefore, further studies are needed to identify the other factors that affect employee WLB and employee performance. This research does not pay attention to how demographic variables such as gender affect employee WLB and also it does not analyze the male and female executives separately. Hence, further research can be carried out to find a gender difference in achieving work-family balance and job performance in the Sri Lankan context. Further, research is needed in order to assess the generalizability of the findings to a broader, more representative population than the selected sample of executives working in IT industry. Not only executives, the research in this area needs to be expanded to the other levels of the organizations such as managers, labors as it may lead to valuable findings. 


\section{References}

Aguinis, H. (2009), Performance Management, $2^{\text {nd }}$ ed, Delhi: Pearson Education Inc.

Allen, E., Bradley, L. and Brown, K. (2000), Explanations for the provision utilization gap in work family policy, Women in Management Review, Vol. 2, No. 4, pp. 321-352.

Armstrong, M. (2000), Performance Management Key Strategies and Practical Guidelines, $2^{\text {nd }}$ ed, London: Kogan Page.

Baltes, B.B., Briggs, T.E., Huff, J.W., Wright, J.A., and Neuman, G.A. (1999), Flexible and Compressed Workweek Schedules: A Meta-analysis of Their Effects on Work-related Criteria, Journal of Applied Psychology, Vol. 84, pp. 496-513.

Beutell, N. and Wittig-Berman, U. (2008), Work-family conflict and work-family synergy for generation X, baby boomers, and matures, Journal of Managerial Psychology, Vol. 23, No. 5, pp. 507-523.

Brough, P., O'Driscoll, M. and Kalliath, T. (2005), The ability of 'family friendly' organizational resources to predict work-family conflict and job and family satisfaction, Stress and Health, Vol. 21, No. 4, pp. 223-234.

Clark, R. (2000), Determinants of work-related family problems employed parents, Journal of Marriage and Family, Vol. 4, No. 6, pp. 881-892.

Clark, S. (2000), Work/Family Border Theory: A New Theory of Work/Family Balance, Human Relations, Vol. 53, No. 6, pp. 747-770.

De Cieri, H., Holmes, B., Abbott, J. and Pettit, T. (2005), Achievements and challenges for work/life balance strategies in Australian organizations, The International Journal of Human Resource Management, Vol. 16, No. 1, pp. 90-103.

Delery, J.T. and Doty, D.H. (1996), Modes of Theorizing in Strategic Human resource Management: Test of Universalistic, Contingency and Configurationally Performance Predictions, Academy of Management Journal, Vol. 39, pp. 802-835.

Dex, S. and Bond, S. (2005), Measuring work-life balance and its covariates, Work, Employment and Society, Vol. 19, No. 3, pp. 627-637.

Flynn, D. and Tannenbaum, S. (1993), Correlates of organizational commitment: Differences in the public and private sector, Journal of Business and Psychology, Vol. 8, No.1, pp. 103-116.

Friedman, S.D. and Greenhaus, J.H. (2000), Work and Family-Allies or Enemies? What Happens when Business Professionals Confront Life Choices, Oxford University Press, New York, NY.

Frone, M.R. (2003), Work-Family Balance, In J. Campbell and L. E. Tetrick (Eds.), Handbook of occupational health psychology, Washington, DC: American Psychological Association, pp. 143-162.

Gouldner, A.W. (1960), The norm of reciprocity: A preliminary statement, American Sociological Review, Vol. 25, pp. 161-178.

Greenblatt, E. (2002), Work/Life Balance: Wisdom or Whining, Organizational Dynamics, Vol. 31, No. 2, pp. 177-193.

Gregory, H. and Milner, A. (2009), Organisational culture and work-life conflict in the UK, The International Journal of Sociology and Social Policy, Vol. 24, No. 12, pp. 12-26. 
Guest, D. (2002), Human Resource Management, Corporate Performance and Employee Wellbeing: Building the Worker into HRM, Journal of Industrial Relations, Vol. 44, No. 3, pp. 335-358.

Guest, D. (2002), Perspectives on the Study of Work-life Balance, Social Science Information, Vol. 41, No. 2, pp. 255-279.

Henry, P. and Anderson, S. (2009), Work-life balance: wisdom or whining, Organisational Dynamics, Vol. 31, No. 2, pp. 177-193.

Higgins, C., Duxbury, L. and Lee, C. (1994), Impact of Life-Cycle Stage and Gender on the Ability to Balance Work and Family Responsibilities, Journal of Family Relations, Vol. 43, No. 2, pp. 144-150.

Hill, E., Hawkins, A., Ferris, M. and Weitzman, M. (2001), Finding an Extra Day a Week: The Positive Influence of Perceived Job Flexibility on Work and Family Life Balance, Family Relations, Vol. 50, No. 1, pp. 49-58.

Hughes, J. and Bozionelos, N. (2007), Work-life balance as source of job dissatisfaction and withdrawal attitudes, Personnel Review, Vol. 36, No. 1, pp. 145-154.

Hunter, J.E. (1986), Cognitive Ability, Cognitive Aptitudes, Job Knowledge, and Job Performance. Journal of Vocational Behaviour, Vol. 29, pp. 340-362.

Kahn, W. (1990), Psychological conditions of personal engagement and disengagement at work, Academy of Management Journal, Vol. 33, No. 4, pp. 692-724.

Kirchmeyer, Y. (2000), Parental leave of absence: Some not so family friendly implications, Journal of Applied Social Psychology, Vol. 29, No. 1, pp. 166-91.

Kopelman, R.E., Prottas, D.J., Thompson, C.A. and Jahn, E.W. (2006), A multi-level examination of work-life practices: is more always better?, Journal of Managerial Issues, Vol. 18, pp. 232-53.

Korpunen, P. and Nápravnfková, A. (2008), Work to live, don't live to work! A cross-sectional study of the work-life balance of higher managers, Master Thesis.

Kossek, E.E. and Ozeki, C. (1999), Bridging the work-family policy and productivity gap: a literature review, Community work and family, Vol. 2, pp. 140-155.

Kumarasamy, M., Pangil, F. and Isa, M. (2015), Individual, Organizational and Environmental Factors Affecting Work-Life Balance, Asian Social Science, Vol. 11, No. 25, pp. 111-119.

Lambert, S.J. (2000), Added benefits: The between work-life benefits and organizational citizenship behavior, Academy of Management Journals, Vol. 43, No. 5, pp. $801-815$.

Lero, M. and Bardoel, E. (2009), Unexpected connections: Considering employees' personal lives can revitalize your business, Sloan Management Review, 38(1), pp.11-19.

Lewis, A. (2008), The case for work-life balance: Closing the gap between policy and practice, Human Resource Management Journal, Vol. 2, No. 1, pp. 64-79.

Lewis, S., Rapoport, R. and Gambles, R. (2003), Reflections on the integration of paid work and the rest of life, Journal of Managerial Psychology, Vol. 18, No. 8, pp. 824-841.

Lo, S. (2003), Perceptions of work-family conflict among married female professionals in Hong Kong, Personnel Review, Vol. 32, No. 3, pp. 376-390.

Loher, B., Noe, R., Moeller, N. and Fitzgerald, M. (1985), A meta-analysis of the relation of job characteristics to job satisfaction, Journal of Applied Psychology, Vol. 70, No. 2, pp. 280-289. 
Maertz, C.P. and Boyar, S.L. (2009), Work-family conflict, enrichment, and balance under level and episodes approaches. Journal of Management, Vol. 37, No.1, pp. 68-98.

McDonald, C. and Bradley, M.P. (2005), Job burnout, Annual Review of Psychology, Vol. 52, No. 12, pp. $397-422$.

Muse, D. and Stamper, H. (2007), When work-family benefits are not enough: The influence of work-family culture on benefit utilization, organizational attachment, and work family conflict, Journal of vocational behaviour, Vol. 5, No. 4, pp. 392-415.

Nisansala, W. A. and Sajeevanie, T.L. (2017), The impact of work life balance on clerical employee job performance: A study of selected two private sector bank branches in Colombo district, $4^{\text {th }}$ International HR Conference, Vol. 4, No. 1, Colombo, Sri Lanka.

Opatha, H.H.H.D.N.P. (2002), Performance Evaluation of Human Resources, Colombo: The Author Publication.

Opatha, H.H.N.D.P. (2003), Research Methods for Human Resource Management, Colombo: The Author Publication.

Opatha, H.H.N.D.P. (2007), Competences as Human Assets, A Perspective, Sri Lankan Journal of Human Resource Management, Vol. 2, No. 1, pp. 62-73.

Osterman, P. (1995), Work/family programs and the employment relationship, Administrative Science Quarterly, Vol. 40, No. 4, pp. 681-700.

Otley, D. (1999), Performance management: a framework for management control systems research, Management Accounting Research, Vol. 10, pp. 363-382.

Pallant, J. (2013), SPSS survival manual, $3^{\text {rd }}$ ed, London, UK: McGraw-Hill.

Perlow, E. (1998), Review of the Satisfaction with Life Scale, Psychological Assessment, Vol. 5, No. 3, pp. 164-172.

Pocock, B. (2005), Work-life 'balance' in Australia: Limited progress, dim prospects, Asia Pacific Journal of Human Resources, Vol. 43, No. 2, pp. 198-209.

Pringle, J., Olsson, S. and Walker, R. (2003), Work/Life Balance for Senior Women Executives: Issues of Inclusion? Stream 19: Gender Perspectives \& Management, pp. 1-16.

Pronk, N. (2005), Worksite Health Promotion: The Challenge of Work and Family Balance, ACSM's Health \& Fitness Journal, Vol. 9, No. 3, pp. 34-36.

Santos, G.G. and Cardoso, C.C. (2008), Work-family culture in academia: a gendered view of work-family conflict and coping strategies. Gender in Management: An International Journal, Vol. 23, pp. 442-457.

Schermerhorn, J. R. (2005), Management, $8^{\text {th }}$ ed, USA: John Wiley \& Sons, Inc.

Scholarios, D. and Marks, A. (2004), Work-life balance and the software worker, Human Resource Management Journal, Vol. 14, No. 2, pp. 54-74.

Sekaran, O. (2006), A general guide to writing research proposal and report: A handbook for beginning research: Kisumu: Options Printers and Publishers.

Soomro, R.B., Gilal, R.G. and Jatoi, M.M. (2011), Examine the impact of human resources management (HRM) practices on employees performance a case study of Pakistani commercial banking sector, Interdisciplinary Journal of Contemporary Research in Business, Vol. 3, No. I, pp. 865-78.

Sullivan, C. and Lewis, S. (2001), Home-based telework, gender, and the synchronization of work and family: perspectives of teleworkers and their co-residents, Gender, Work and Organisation, Vol. 8, No. 2, pp. 123-145. 
Thanacoody, R.P., Bartram, T., Barker, M. and Jacobs, K. (2006), Career progression among female academics, A comparative study of Australia and Mauritius, Women in Management Review, 21.

Thibaut, J.W. and Kelley, H.H. (1959), The social psychology of groups, New York: John Wiley \& Sons.

Thomas, L.T. and Ganster, C. (1995), Impact of family-supportive work variables on workfamily conflict and strain: a control perspective, Journal of Applied Psychology, Vol. 80, pp. 6-15.

Thompson, C. and Prottas, D. (2006), Relationships among organizational family support, job autonomy, perceived control, and employee well-being, Journal of Occupational Health Psychology, Vol. 11, No. 1, pp. 100-118.

Thompson, P., Chandra, K. and Charanjeet, S. (1999), Empirical analysis of work-life balance policies and its impact on employee's job satisfaction and performance. American Journal of Theoretical and Applied Statistics, Vol. 4, No. 2, pp. 33-43.

Van Dyne, L. and Ang, S. (1998), Organizational citizenship behavior of contingent workers in Singapore, Academy of Management Journal, Vol. 41, No. 6, pp. 692-703.

Voydanoff, P. (2004), The Effects of Work Demands and Resources on Work-to-Family Conflict and Facilitation, Journal of Marriage and Family, Vol. 66, No. 2, pp. 398-412.

Wayne, J.H., Randel, A.E. and Stevens, J. (2006), The role of identity and work-family support in work-family enrichment and its work-related consequences, Journal of Vocational Behaviour, Vol. 69, No. 3, pp. 445-61.

Weisenfeld, K.J., Raghuram, G.M. and Garud, S. (2001), Role stressors, mood spillover and perceptions of work-family conflict in employed parents, Academy of Management Review, Vol. 37, No. 11, pp. 837-868.

Woodward, D. (2007), Work-life balancing strategies used by women managers in British “modern" universities, Equal Opportunities International, Vol. 26, No. 1, pp. 6-17. 